[8] Klokar, N. I. (2010). Instytuatsiynyy rozvytok ta profesiynyy rozvytok personalu zakladu pislyadyplomnoyi pedahohichnoyi osvity. Kyiv: KOIPOPK, 192.

[9] Brazhe, T. G., Zaborshhikova, M. M. (1996). Samodiagnostika proffesional'noj deyatel'nosti uchitelja. Diagnosticheskie i obuchayushhie metodiki. Saint Peterburg, 361.

[10] Pikel'na, V. S. (2004). Upravlinnya shkoloyu. Kharkiv: Osnova, 112.

[11] Yel'nikovoyi, H. V. (Ed.) (2010). Kvalifikatsiyni vymohy do profesiynoyi diyal'nosti pedahohichnykh pratsivnykiv. Kyiv-Cherkasy, 96.

[12] Kohut, I., Stadnyy, Ye. (2015). Byudzhet osvity ta nauky 2016: shcho pryynyaly deputaty. CEDOS. Available at: http://www.cedos.org.ua/uk/osvita/biudzhet-osvity-ta-nauky-2016-shcho-pryinialy-deputaty

[13] Mizhnarodnyy fond «Vidrodzhennya». Available at: https://issuu.com/irf_ua

\title{
ELABORATION OF THE MODEL OF FORMATION OF READINESS OF FUTURE PRIMARY SCHOOL TEACHERS TO THE USE OF LEARNING-PLAYING TECHNOLOGIES
}

\author{
Marina Marko \\ Department of methods of labor and vocational training and arts and applied arts \\ Drohobych Ivan Franco State Pedagogical University \\ 24 Ivan Franko str., Drohobych, Lviv region, Ukraine, 82100 \\ m.marko1202@gmail.com
}

\begin{abstract}
The study characterizes the structural-functional model of formation of readiness of students of the specialty "Primary education" to using learning-playing technologies in the educational process. Among general modeling forms there was chosen the combined model (graphic descriptive scheme) of the structural-functional type. There was substantiated the main idea of modeling of the process of formation of future primary school teachers' readiness to using learning-playing technologies, especially, elaboration of such structural-functional model that would allow to improve the effectiveness of this process, to make it correspondent to social requirements and expectations from realization of New Ukrainian school principles. It was determined, that the object of modeling is the process of formation of readiness to using learning-playing technologies, realized within the general system of the professional training of future primary school teachers. The aim of the model creation was formulated: elaboration of the schematic construction that embodies the abstract structure and the real projected process and result. The theoretical-methodological approaches to the model projecting process were separated, namely: system, activity, personally oriented, competence. The main blocs of the elaborated structural-functional model were separated, especially, target, content, procedural and resulting.
\end{abstract}

Keywords: structural-functional model, learning-playing technologies, teacher's readiness formation, professional activity.

\section{Introduction}

In the last years the social discourse about pedagogical education cardinally changes, so its content orients farther more on the competence, mobility and readiness of future teachers to realize the professional activity under condition of the New Ukrainian school creation. Today graduates of pedagogical HEI have enough theoretical knowledge in the subject branch, but often have complications with their use in the professional activity. The higher pedagogical education must help future teachers on the way of their formation as competent and creative specialists, who know their subject perfectly and have diverse technologies of its teaching, including learning-playing ones.

Analyzing possibilities of the use of the methodology of pedagogical studies on the outlined problem, the question about choosing the instrumental base for the analysis and projecting of the pedagogical activity in the process of formation of "Primary education" students" readiness to using learning-playing technologies in the future professional activity becomes urgent. In the study 
was chosen the method of this process modeling as a method of cognition, higher form of generalization and visual presentation of the studied phenomenon.

\section{Analysis of literary data and statement of the problem}

Most scientists analyze the pedagogical technology as a system that gradually realizes the preliminary projected learning-upbringing process in practice [1]. It is often defined as systematicity, constructing and modeling of the educational process that guarantee the attainment of set aims [2]. Taking into account the aforesaid, in the study was chosen the method of this process modeling as a method of cognition, higher form of generalization and visual presentation of the studied phenomenon.

A lot of works are devoted to the problem of objects and pedagogical reality phenomena modeling. The analysis of modern scientific-pedagogical studies confirms the wide popularity of the modeling method. Modeling is interpreted by scientists as:

1) the method of studying objects on their models-analogues of a certain fragment of the natural or social reality; .... The construction and study of models of really existent subjects and phenomena and constructed objects [3];

2) the theoretical method of studying processes and states using their real (physical) or ideal, first of all, mathematical models [4];

3) the method of scientific research that realizes the series of functions: illustrative, explanatory, criterial, heuristic, prognostic, transforming [5] and others.

The result of pedagogical modeling is a creation of a pedagogical model that is a totality of notions and schemes; represents the educational process not directly in the complicated, non-embracing unity of all its multiform manifestations and properties, but in generalized (indirect) form, accenting attention only on essential features. That is the integral pedagogical model is built on the distinctly determined principles, represents the educational process in a "pure" form as a theoretical-logical scheme, deprived of all unessential and occasional things [6].

Scientists separate educational models and learning ones. Educational models include the logically structured system of elements: aims and sense of education, educational programs and curriculums, pedagogical technologies and technologies of the educational process management. A learning model consists of a pedagogical technique and didactic base that includes the system of methods and learning organizational forms [7]. Informational and operational learning models are also distinguished [8].

At pedagogical modeling are often used such formal criteria as: integrity, stability, observability, comprehensiveness [9], easiness, adequacy [10].

But there are no system scientific searches on the problem of modeling of the process of formation of future teachers' readiness to using learning-playing technologies.

\section{Aim and tasks of research}

The aim of the research is the description of the theoretical model of the process of formation of future primary school teachers' readiness to using learning-playing technologies.

The following tasks were set for attaining this aim:

1. Substantiation of the choice of forms and look of the model.

2. Elaboration of the structural-functional model of the process of formation of readiness to using learning-playing technologies.

3. Analysis of blocs of the author model.

\section{Materials and methods}

Modeling as a method of cognition gains the special importance, because it gives a possibility to synthesize existent ideas about the studied object in the logic successiveness, and also to trace rather easy the dialectic dependence between elements and subsystems of the studied system. The search for the most rational variant of projecting the model of formation of students' readiness to using learning-playing technologies was realized on the base of the study of different approaches to the choice of the model type, scientifically grounded foresight of the modern state of the peda- 
gogical system, its main elements and components on the base of understanding tendencies of its development and the new content appearance.

We have accepted the following definition of a model for our research: "Model it is a mentally presented or materially realized system that reflects or recreates an object of the research and is able to replace it in such a way that its study gives us new information about this object" [11].

The process of projecting of formation of future primary school teachers' readiness to using learning-playing technologies in the professional activity is based on such theoretical-methodological approaches: system, activity, personally oriented [12]; competence [13].

Composing the theoretical-methodological base of our study the aforesaid approaches, used in the organic unity and adding each other, allow to consider the process of formation of future primary school teachers' readiness to using learning-playing technologies in different aspects and to provide its unity and effectiveness.

The results of the analysis of theoretical sources on the problem of formation of future primary school teachers' readiness to the professional activity, including using learning-playing technologies, allowed us to elaborate the author model.

It is well-known, that the choice of forms and look of the model (structural-functional, formalized, imitational) depends on the aim of the process of such modeling. Among the general forms of modeling (textual, descriptive, graphic, combined) we have chosen the combined (graphic-descriptive scheme) model of the structural-functional look.

\section{Experiment}

The main idea at the modeling of the process of formation of future primary school teachers' readiness to using learning-playing technologies is elaboration of such structural-functional model that would allow to improve the effectiveness of this process, to make it correspondent to social requirements and expectations from realization of New Ukrainian school principles.

It was determined, that the content of the pedagogical model depends on the aim of the research and allows to trace different sides and characteristics of the research object.

The object of modeling is the process of formation of readiness to using learning-playing technologies, realized within the general system of the professional training of future primary school teachers.

The aim of creation of the model of formation of future primary school teachers' readiness to using learning-playing technologies in the professional activity is elaboration of the schematic construction that embodies the abstract structure and the real projected process and result. Thus, to imagine the studied process in dynamics, we have built and substantiated the author structural-functional model that allows to reflect: aim, theoretical-methodological principles, structural blocs (target, content, procedural, resulting) that due to the influence of correspondent pedagogical conditions, using learning-methodical support, allow to receive the prognosticated result - the high level of future primary school teachers' readiness to using learning-playing technologies in the professional activity (Fig. 1).

The elaborated structural-functional model is characterized by the following features:

1) totality, represented in the unity of its objective (aim, tasks, content of the professional training of future primary school teachers) and subjective components (features of the learning cognitive activity of students, specificity of interaction between students and teachers, students-probationers and pupils and so on);

2) structuredness, determined by the unity of its main structural-functional blocs (target, content, procedural, resulting);

3) systematicity and phasing of the model realization under conditions of the multi-level educational process;

4) dynamics that is the continuous change, development, perfection, renovation of the content forms and methods of training students to using learning-playing technologies in the future professional activity;

5) integrity, when the interconnection of structural-functional blocs of the model reflects the logic of the studied process in the organizational aspect and provides a possibility of its com- 
prehensive consideration at correlating the aim and result; in the content aspect - there is provided the logic interconnection of disciplines of the general pedagogical, methodical and special (playing-technical) training;

6) recreation ability that allows recreation in the process of professional training of future primary school teachers;

7) adaptability that is the model adaptation to the process of professional training of future primary school teachers, realized under new or changed conditions.
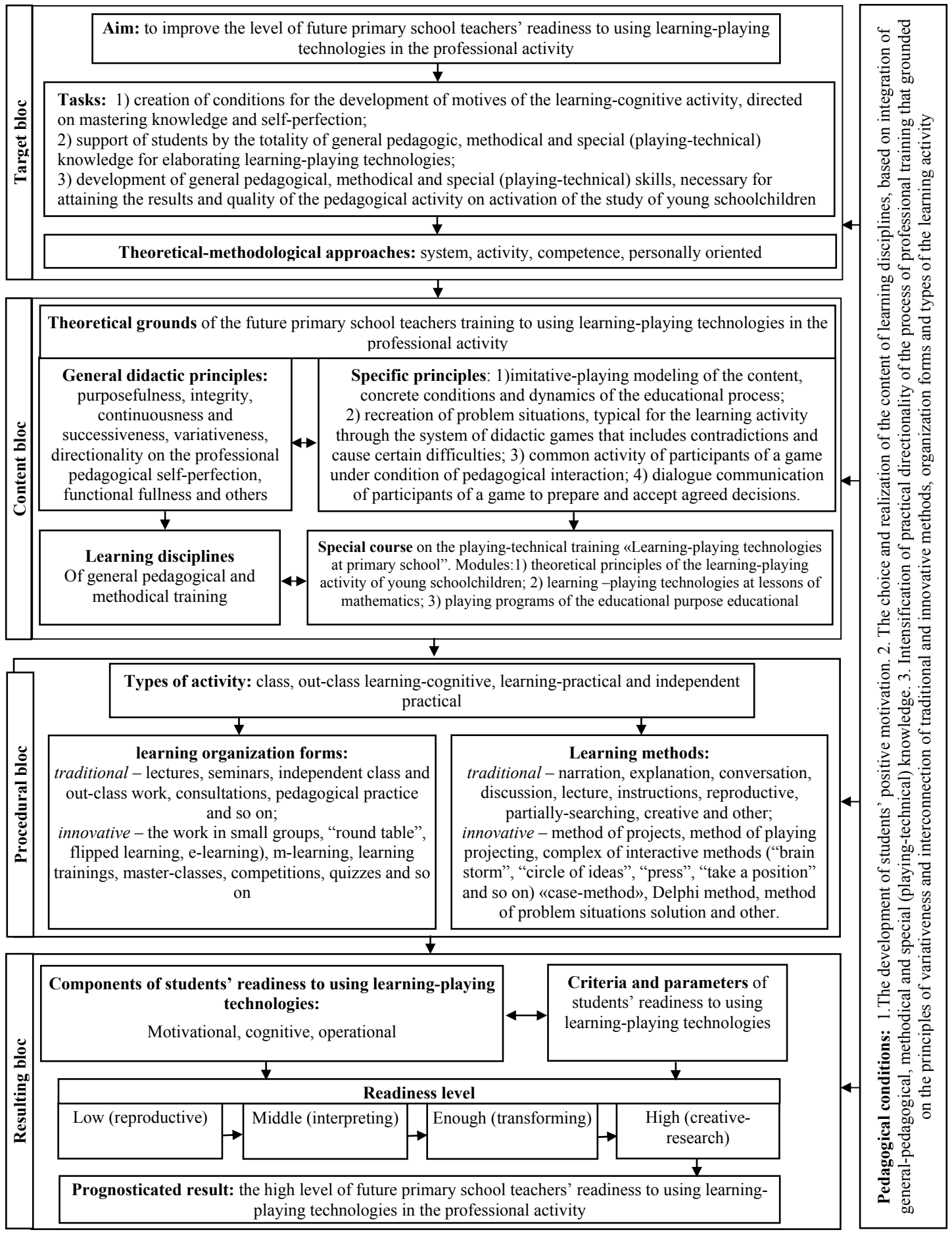

Fig. 1. The structural-functional model of formation of future primary school teachers' readiness to using learning-playing technologies in the professional activity 
The author structural-functional model of future primary school teachers' readiness to using learning-playing technologies in the professional activity includes the following blocs: target, content, procedural and resulting. Let's consider them in detail.

The target bloc characterizes the social demand, aim, tasks, theoretical-methodological approaches of the studied process. The social demand for the improvement of the quality of the professional training of future primary school teachers includes social requirements to the formation of the high level of professional competence in students. This social demand determines the aim and tasks of the educational process, realized according to the Standards of higher education of Ukraine (knowledge field - 01 "Education/Pedagogy"; specialty - 013 "Primary education").

The aim of the studied process is to improve the level of future primary school teachers' readiness to using learning-playing technologies in the professional activity. So, the purpose of the target bloc is the theoretical-methodological substantiation and determination of the final result of the realized pedagogical interaction on formation of future primary school teachers' readiness to using learning-playing technologies.

The content bloc of the studied process reflects its content, determined taking into account principles that form the base of teachers' and students' activity in the system of professional training. We have separated the following principles: purposefulness, integrity, continuousness and successiveness, variativeness, directionality on the professional-pedagogical self-improvement, functional fullness.

The content of the studied process is determined, taking into account its aim, tasks, principles and may be presented by three content blocs: general pedagogical, methodical and special (playing-technical). Each of them includes the activity, directed on the formation of all separated components of future primary school teachers' readiness to using learning-playing technologies (motivational, cognitive, operational).

The process of formation of future primary school teachers' readiness to using learning-playing technologies provides the use of the wide arsenal of methods and forms of the study organization, typical to higher school, presented in the procedural bloc.

In the process of future primary school teachers' professional training are mainly used the learning methods, oriented on the classification by dominant knowledge fields, especially: verbal, visual, practical, logical, control and assessment of the educational process results and so on. In the context of the research we stopped most often on innovative methods, especially methods of projects and playing projecting.

In the modern educational process the activity on a project creation is called projecting that provides students' independent activity and their instructing by a teacher that has gotten the popular name "scaffolding" [14].

So, the methods of projects - is a totality of students' steps and actions in the certain successiveness to attain the set task - solution of a learning or professional problem, personally important for an author of a project and formed as a final material product, presentation, portfolio and so on.

Educational practice and our experience testify that students' participation in real projects for elaborating learning-playing technologies is the one of most effective learning strategies, directed on the development of not only professional knowledge and competences, but also skills of fast adaptation to modern requirements, set for primary school by the society.

The playing projecting - is the one of widespread ways of intensive study, aimed at the process of creation and improvement of projects in the team work regime. The main feature of this method is the interaction of groups' participants from "functional-role" positions that provides absolutely another view on the studied object from the aspect, unusual for students that makes the positive cognitive effect possible.

The process of formation of future primary school teachers' readiness to using learning-playing technologies provides the use of diverse forms of the study organization, among them: lectures, seminars, independent class and out-class work, consultations, pedagogical practice and so on.

In the process of the research the training object was mainly the probation of learning-playing technologies, elaborated by students, their maximal approximation to real situations, possible 
at lessons in primary classes. It was some kind of a "testing ground", where the discussion and correction of students' learning projects were realized by joint efforts.

The resulting bloc structural-functional model of formation of future primary school teachers' readiness to using learning-playing technologies provided the establishment of concrete results of the studied process realization that is the transfer to the higher level of students' readiness to using learning-playing technologies in the professional activity as an integrative characteristic that includes motivational, cognitive and operational components.

The result of introducing the author structural-functional model was determined by the creative-research (high), transforming (sufficient), interpreting (satisfactory) and reproductive (low) levels of future primary school teachers' readiness to using learning-playing technologies in the professional activity and also by the distinctly used criteria and parameters.

\section{Results of research}

The interconnection of the structural blocs of formation of students' readiness to using learning-playing technologies has provided its stability. The offered blocs completely represent the integral character of the studied process that give grounds to consider them as necessary, sufficient and such that provide the dialectic interconnection and logic of the process of formation of students' readiness to using learning-playing technologies.

\section{Conclusions}

1. Among the general forms of modeling we have chosen the graphic-descriptive one as a structural-functional scheme.

2. The offered structural-functional model may be assessed as a method, way, due to which teachers will build the educational process to improve the level of students' readiness to using learning-playing technologies at primary school. To underline the content-methodological essence of this model, it may be also presented as a form of movement of the content of future teachers' training in the direction of elaboration, organization and realization of didactic games that allow to activate and to diversify the educational activity of young schoolchildren.

3. The elaborated structural-functional model of formation of future primary school teachers' readiness to using learning-playing technologies is based on the interconnection of target, content, procedural and resulting blocs and reflects the complex realization of pedagogical conditions.

\section{References}

[1] Bespal'ko, V. P. (1995). Pedagogika i progressivnye tehnologii obucheniya. Moscow: Novaya shkola, 412 .

[2] Klarin, M. V. (1995). Innovacii v mirovoi pedagogike: obuchenie na osnove issledovanija, igry, diskussii. Analiz zarubezhnogo opyta. Riga: NPC «Eksperiment», 176.

[3] Il'ichev, L. F., Fedoseev, P. N., Kovalev, S. M., Panov, V. G. (Eds.) (1983). Filosofskii enciklopedicheskii slovar'. Moscow: Sov. enciklopediya, 840.

[4] Polonskii, V. M. (1995). Nauchno-pedagogicheskaya informaciya: slovar'-spravochnik. Moscow: Novaya shkola, 352 .

[5] Horuzha, L. L. (2003). Etichna kompetentnist' maibutn'ogo vchitelya pochatkovih klasiv: teoriya i praktika. Kyiv: Presa Ukraini, 320.

[6] Teslenko, A. N. (2010). Pedagogika : uchebn. Posobie. Astana: EAGI, 465.

[7] Bershadskii, M. E., Guzeev, V. V. (2003). Didakticheskie i psihologicheskie osnovaniya obrazovatel'noi tehnologii. Moscow: Centr «Pedagogicheskii poisk», 178.

[8] Skrypchenko, O. V., Dolyns'ka, L. V., Ohorodniychuk, Z. V. (2001). Vikova ta pedahohichna psykholohiya. Kyiv: Prosvita, 416.

[9] Zotov, A. F. (1976). Idealizirovannaya model' kak osnova nauchnoi teorii. Voprosy povysheniya effektivnosti teoreticheskih issledovanii v pedagogicheskoi nauke. Moscow: Pedagogika, 231.

[10] Volyk, L. V. (2005). Pidhotovka maybutnikh uchyteliv pochatkovoyi shkoly do polikul'turnoho vykhovannya uchniv. Kiev, 235.

[11] Shtoff, V. A. (1963). Rol' modeli v poznanii. Leningrad: Izd-vo LGU, 128. 
[12] Andrushchenko, V., Divins'ka, N., Korol'ov, B. (2008). Osobystisno oriyentovani tekhnolohiyi navchannya i vykhovannya u vyshchykh navchal'nykh zakladakh. Kiev: Pedahohichna dumka, 256.

[13] Pometun, O. I. (2004). Dyskusiya ukrayins'kykh pedahohiv navkolo pytan' zaprovadzhennya kompetentnisnoho pidkhodu v ukrayins'kiy osviti. Kompetentnisnyy pidkhid u suchasniy osviti: svitovyy dosvid ta ukrayins'ki perspektyvy. Kiev: «K.I.S.», 112.

[14] Panfilova, A. P. (2012). Razvitie issledovatel'skih kompetentnostei magistrantov pri samostoyatel'noi rabote s ispol'zovaniem skyeffoldinga. SaintPeterburg.: Izd. RGPU im. A. I. Gercena, 20-25.

\title{
DEVELOPMENT OF A MODEL OF PROFESSIONAL READINESS FOR FUTURE PILOTS STUDYING AT HIGHER EDUCATION MILITARY INSTITUTES (HEMI)
}

\author{
Roman Nevzorov \\ Department of Flight Tactics and Operation \\ Ivan Kozhedub Kharkiv University of Air Force \\ 77/79 Sumska str., Kharkiv, Ukraine, 61023 \\ roman.nevzorov@list.ru
}

\begin{abstract}
The research seems to be important because Ukraine's integration into international security and European educational systems provide for a high level of professional competence of Ukrainian Armed Forces officers (Ukraine AF), which is considered to be mandatory for assigned task execution, military personnel's coordination in peacekeeping operations and joint military exercises with different countries, as well as for training, experience exchange, and competitiveness. The purpose of the research: The purpose of the article is to develop a model of best practice for future pilots in simulators. Methods of the research: The main method of the research is analysis of literature and documents regulating flight operations, in order to study issues and theoretical and methodological principles of the research and combat flight modeling in simulators to determine the nature and specifics of pilots' activity at different stages of combat flights. Results of the research: The article describes a model of professional practice for future pilots, which includes components of their readiness for combat missions. The practical significance: The model is aimed at teachers' adaptation to new conditions of training of future pilots at HEMIs and at improvement of simulator training.
\end{abstract}

Keywords: pilots' professional readiness, combat flight simulation, simulator, simulation practice.

\section{Introduction}

Practical measures regarding Euro-Atlantic integration of Ukraine require modern pedagogical technologies, rethinking of concepts of training of military specialists of Ukrainian Air Force (Ukraine AF).

Ukrainian Air Force was established in 2004 by combining Air and Air Defense Forces of the country. This maneuverable type of forces is designed to protect airspace, destroy enemies' facilities from air, to provide air support for own troops, to land and air born invasion and air transportation of troops and materials, and aerial reconnaissance. The following planes are adopted in the Air Force: MiG-29, Su-27, Su-25, Su-24M, Su-24MR, Il-76MD, An-26, An-24, L-39, anti-aircraft missile systems S-300, and "Buck" in various versions.

In current conditions of anti-terrorist operation (ATO) and due to the Russian aggression, training of military pilots, effective planning of the use of forces in air combats against enemy's attacks and air strikes on objects (force grouping) in response are urgent, so it is believed to be important for pilots to practice their skills, particularly tactical flight tasks in the day and night, live firing and bombing practice. It is important to train pilots to protect against air strikes on key objects and troops. Special attention should be paid to organization and cooperation between the groups and means of the Ukrainian Armed Forces, other military formations and law enforcement. Therefore, the main strategy of pilot training should consist of the study and development of ef- 